Article

\title{
Does Sustainability Push to Reshape Business Models? Evidence from the European Wine Industry
}

\author{
Stéphane Ouvrard ${ }^{1}$, Sajjad M. Jasimuddin $1, * \mathbb{C}$ and Antonio Spiga ${ }^{2}$ \\ 1 Strategy, Entrepreneurship, Sustainability Department, Kedge Business School, 680 Cours de la Libération, \\ 33405 Talence, France; stephane.ouvrard@kedgebs.com \\ 2 Recherche Économie, Université de Bordeaux, avenue Léon Duguit, 33608 Pessac, France; \\ antoniospiga@orange.fr \\ * Correspondence: sajjad.jasimuddin@kedgebs.com
}

Received: 16 January 2020; Accepted: 23 March 2020; Published: 24 March 2020

\begin{abstract}
The wine industry is not free from environmental concerns. The paper intends to explore the owners/managers' interest in environmental sustainability issues in their business model and to empirically understand a business model in the wine industry. Taking a qualitative approach, this exploratory study allows us to observe the phenomenon in a natural setting. Eleven interviewees were selected from wineries based in France and Italy. The study reveals that sustainability is an important issue in wine businesses that shapes the business model. Highlighting the environmental aspects of wine production, the four components of a business model, i.e., performance, resources, innovation, and value creation (PRIV), have emerged from the interviews. The sustainability and environmental issues are reflected in business models in the wine industry. The paper explains how these components of a business model work together to ensure sustainability practices by wine producers. This study proposes a model for future applications in winery businesses. The paper helps to understand that wine producers are very keen on environmentally friendly wine businesses.
\end{abstract}

Keywords: business model; environment; innovation; performance; sustainability; wine

\section{Introduction}

Recently, the interest in a business model has grown in significance as it is associated with enhancing a firm's competitive advantage [1-3]. a business model describes how a firm operates its business [4,5]. a business model is not, in itself, a strategy [6]. Rather, it is an abstraction of a firm's strategy, i.e., the direct result of strategy. a business model is a simplified representation of a company's activities. According to Casadesus-Masanell and Ricart [6], a business model refers to the logic of the firm, the way it operates, and how it creates value for its stakeholders. It describes how a given actor "chooses to connect with factor and product markets" [7].

Every company realizes that it cannot survive and succeed in a global competitive environment without a business model [8]. As a result, every organization is expected to have developed its business model [6]. Presenza et al. [9] investigate the relationship between business model innovation and sustainability in the hospitality and tourism industry. Lopes et al. [10] articulate a conceptual review of business models, innovation, and sustainability transition in the context of a health business. This is not an exception for the wine industry. In a globalized market, intense competition in the wine sector leads to critical management issues for wine producers. Today's society warrants environmental accountability [11]. The wine sector has a reputation as being environmentally safe [12].

Since a sustainable business model serves as a key driver of the competitive advantage of a firm [13], environmental sustainability is gaining attention in business models of the wine industry. Due to the unique feature of the product, wine estate owners and managers need to critically review their 
business models, set up strategies, and measure their performance. In this competitive environment, business models are often too complex [6]. Authors [7,8,14,15] have focused on business models in relation to their components. For example, Zott and Amit [7] explained, in detail, business model in relation to the interconnections among their elements. The insights of Zott and Amit $[7,8]$ inspired the theoretical foundation of this study. The paper intends to shed light on environmental sustainability in a business model for the wine industry.

Scholars [11,16] are concerned over winery impacts on society and the environment. Due to the intense pressure from various stakeholders, winery owners and managers are increasingly adopting environmental practices to ensure a more sustainable future. This implies that they have an interest in managing the environmental aspects of wine grape cultivation and wine production. We ask how owners/managers' perceptions of environmental practices influence and shape the business model in the wine industry. The purpose of this study is twofold: First, to explore owners/managers' perception of the sustainability and environmental issues that are reflected in a business model in the wine industry and, second, to identify the components of a business model of wine companies. This will help to understand that wine producers are very keen on environmentally friendly wine businesses.

The paper is organized as follows. In the second section, the previous literature is reviewed to understand environmental sustainability and business models in the wine industry. In the third section, the research methodology is outlined. Section four analyzes the empirical findings of the research, followed by a discussion of the elements of a business model that relates to sustainability. The paper highlights the theoretical and managerial implications of its findings and concludes by reflecting on several limitations of the study.

\section{Literature Review}

A strong academic interest in the business model (BM) is relatively recent [14]. The business model of a firm describes the architecture that helps create and deliver value to customers by employing the resources at its disposal [17]. In other words, it is a guide to understand how a firm can successfully deliver value to its customers. Scholars [1,17-21] have discussed business models in terms of the firm's value proposition and market segments. For example, Achtenhage et al. [18] claim that a business model helps to achieve sustained value creation. Parallel to this, Wirtz et al. [1] contend that it helps to describe how information and products/services are generated by means of a company's value-added component. Designing a business model is also crucial for a wine company. Unlike other commodities, wine is a complex, symbolic, and emotional product. a wine company needs to share ideas with its customers about the wine it produces.

Wine production and distribution matters that are associated with environmental issues include land, water, energy, and chemical use, the generation and management of organic and inorganic waste streams, the production of greenhouse gas emissions, and the impact on ecosystems [12]. The main focus of sustainable business is to preserve the environment to guarantee the wellbeing of future generations [22]. Increasing the sustainability awareness of the owner and manager has led to the proliferation of sustainability initiatives in the wine businesses. Parallel to this, Olaru et al. [23] argue that sustainability of the wine industry involves environmental concerns in the grape production and processing systems. That is, various environmental aspects of wine grape cultivation and wine production cover the requirements of precision in sustainable viticulture, product safety, consumer health, risks to the environment, and valuing of heritage, historical, cultural, and ecological and landscape issues [23].

Stakeholder pressures drive the implementation of sustainable practices, which, in turn, results in product innovation, pollution prevention, and stewardship of natural resources [24-26]. More specifically, consumers in the 21st century have a strong demand for wine that is produced using "green" production practices [23,27]. People, in general, believe that high costs are a barrier to adopting environmental strategies $[11,28]$. However, wine producers know that consumers are ready to pay 
a premium price for wine that follows green production. That is why wine producers make efforts to produce wine in a sustainable way to ensure better quality than the conventionally produced wine.

\section{Research Method}

This section describes the research design and covers research site selection and data collection and analysis. This paper reports on a qualitative study, which allowed us to observe the phenomenon in an organizational setting in order to explore the components of a business model.

It is to be noted that the 'Old World' producers (e.g., France, Denmark, Germany, Italy, Portugal, Spain, and the UK) are major exporters of wine and they control $64 \%$ of the export market share of wine. On the other hand, the 'New World' is the term for non-European wine countries, where the wine industry was born along with the development of colonialism, when European explorers began to establish vineyards. These countries include Argentina, Australia, Chile, New Zealand, South Africa, and the United States, which together have the remaining 36\% market share [26]. The wine companies under study are based in France and Italy. There are several reasons to study the wine industry from two countries among the 'Old World' producers.

In Southern European countries, particularly France and Italy, tradition and heritage from the past are key factors. Most wineries are family-owned, and a particular emphasis is put on the quality of wines. Their business model is based on the region and limited yields of production in order to maintain quality. Basically, we adopted a snowball technique based on the following sampling criteria: family-owned, active involvement of the ownership on the business, traditional focus on product, ownership of the production (vine growing), and transformation (winemaking) chains.

France and Italy are major players in the global wine industry, and there has been a growing interest in developing sustainable wine production initiative in these countries. For example, Tyler, Lahneman, Beukel, et al. [29], in their study, show that "New World" (e.g., Australia, the United States) wineries are less likely to adopt environmental practices than wine companies in Italy and France. Moreover, a proliferation of initiatives relating to sustainable wine businesses started officially in Italy in 2010 [30].

\subsection{Participants}

A total of 11 interviewees were chosen purposefully to allow themes or patterns associated with an environmental sustainability business model to emerge. The participants represented both wine estate owners and general managers, all of whom had worked more than ten years in the wine company. The participants described their experiences in designing business models within their organizational setting. They were encouraged to freely express their personal experiences, taking sustainability and environmental issues into account.

\subsection{Data Collection}

The interview protocol was distributed to the participants with an information pack prior to the interview. Our semi-structured interviews took place between 7 May 2015 and 23 June 2017. The questions asked were sufficiently open-ended to allow the interviewees to participate in conversation. This approach facilitated conversation without restricting the emergence of other topics during the course of the interviews. Each interview took between one hour and two hours and was tape recorded.

\subsection{Data Analysis}

The data analysis procedure proposed by Russell, Wutich, and Ryan [31] was employed in this research. Data analysis involved transcription, coding, and analysis, which was done manually. The text analysis technique suggested by Russell et al. [31] involves five tasks: (i) identify themes and sub-themes; (ii) describe the core and peripheral elements of themes; (iii) build hierarchies of themes; (iv) attach them to chunks of actual text; and (v) finally link them into a theoretical model. 
We started with reviewing the interview recordings and transcripts. The associated themes were then put together and their common properties were found while referring back to the context in the transcripts. The transcripts helped to evolve the key components of a business model within the wine industry that was related to sustainability.

\section{Results}

All of the wineries under study sell bottled wines in both the domestic and international markets. Table 1 depicts the wine estates, which are all family businesses. The interviewees were either the owners or general managers, with broad managerial responsibilities enabling them to make strategic decisions. Moreover, they all had a great deal of experience in the wine industry (more than ten years), along with different backgrounds (e.g., finance, agricultural engineer, sales).

Table 1. List of estates.

\begin{tabular}{|c|c|c|c|c|c|c|c|}
\hline Interview & Location & Country & Family Business & Position (Interviewee) & Date of the Interview & Duration & Surface \\
\hline $\mathrm{A}$ & Bordeaux & France & Yes & General Manager & 7th May, 2015 & $1 \mathrm{~h}$ & 20 ha \\
\hline B & Sardinia & Italy & Yes & Owner Manager & 25th May, 2016 & $1 \mathrm{~h}$ & 80 ha \\
\hline C & Languedoc & France & Yes & Owner Manager & 22th July, 2016 & $2 \mathrm{~h}$ & 350 ha \\
\hline $\mathrm{D}$ & Sardinia & Italy & Yes & Marketing Director & 6th October, 2016 & $1 \mathrm{~h}$ & 98 ha \\
\hline E & $\begin{array}{l}\text { Côtes du } \\
\text { Rhône }\end{array}$ & France & Yes & Owner Manager & 3rd December, 2016 & $1 \mathrm{~h} 30$ & 32 ha \\
\hline $\mathrm{F}$ & Bordeaux & France & Yes & General Manager & 9th January, 2017 & $1 \mathrm{~h} 30$ & 28 ha \\
\hline G & $\begin{array}{l}\text { Côtes de } \\
\text { Gascogne }\end{array}$ & France & Yes & Owner Manager & 18th June, 2017 & $1 \mathrm{~h}$ & 70 ha \\
\hline $\mathrm{H}$ & Bordeaux & France & Yes & General Manager & 13th June, 2017 & $1 \mathrm{~h}$ & 40 ha \\
\hline I & Bordeaux & France & Yes & Owner Manager & 23th June, 2017 & $1 \mathrm{~h}$ & 8 ha \\
\hline $\mathrm{J}$ & Bordeaux & France & Yes & General Manager & 25th January, 2017 & $1 \mathrm{~h}$ & 16 ha \\
\hline K & Sardinia & Italy & Yes & Owner Manager & 24th February, 2017 & $1 \mathrm{~h}$ & 2 ha \\
\hline
\end{tabular}

Based on a theoretical base and the coded procedures of Russell et al. [31], the first part of the text analysis allowed us to identify the four main themes (Table 2): performance (P), resources (R), innovation (I), and value creation (V). These themes have been broken down into three different sub-themes: financial indicators (P1), non-financial indicators (P2), operational efficiency (P3), skills and capabilities (R1), infrastructures (R2), technologies (R3), new product/service (I1), quality (I2), sustainability (I3), brand equity (V1), financial flows (V2), and knowledge sharing (V3). These four components contribute to the business model design in the wine industry context and also help to relate broader environmental sustainability issues in wine businesses. These factors are explained, in turn, below.

Table 2. Categorization and coding of the data collected.

\begin{tabular}{|c|c|c|c|c|c|c|c|c|c|c|c|}
\hline \multicolumn{3}{|c|}{ Performance (P) } & \multicolumn{3}{|c|}{ Resources (R) } & \multicolumn{3}{|c|}{ Innovation (I) } & \multicolumn{3}{|c|}{ Value Creation (V) } \\
\hline P1 & P2 & P3 & R1 & R2 & R3 & I1 & I2 & I3 & V1 & $\mathrm{V} 2$ & V3 \\
\hline 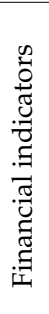 & 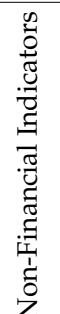 & 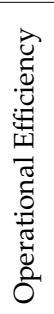 & 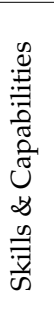 & 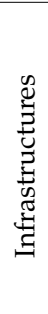 & 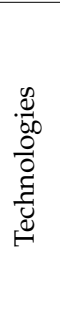 & 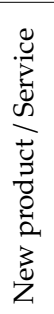 & $\begin{array}{l}\stackrel{\overrightarrow{7}}{0} \\
\frac{\pi}{2} \\
\vec{a}\end{array}$ & 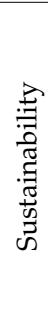 & 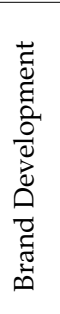 & 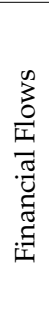 & 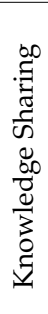 \\
\hline
\end{tabular}

\subsection{Performance $(P)$}

The good performance of a firm can ensure its survival and growth. Considering the financial indicator (P1), a key indicator of performance, our French interviewee, A, indicates: "Performance for us 
is first related to financial aspects, rather than to brand and quality". This focus on financial aspects is also observed by another French respondent, E, who comments on sale revenue: "What represent best my business model is my commercial performance". For his part, the French interviewee, $\mathrm{H}$, considers that 'you are performing when you can cover your costs! Financial performance is the key for us'. He admits that they cannot afford losing an extra harvest, even if their work is naturally exposed to climatic hazards. Their distribution system is secured through the "Place de Bordeaux" market place: $90 \%$ of their wine production is sold to "négociants" (wine merchants). However, the French participant, I, considers that financial indicators are not the most important criteria when managing a wine estate. He explains: "Nowadays, a financially performing wine estate requires a critical size. It was not the case twenty years ago". The business model may become tricky when the production cost is on the rise. This is the case with natural wine. According to him, the only solution is to increase the level of production. "However, I do not expect an economic profitability ... What I am looking for is a high-quality image ... We thrive to produce wine where the emotional factor is very important. That's why the quality of our wines must be impeccable".

Financially speaking, what seems important is to increase the value of the wine estate with a long-term perspective. French interviewee, J, who is also involved in sustainable practices, admits "from the pure economic perspective, it is a nonsense. During harsh vintage, for examples, such as 2012 and 2013, without using any chemicals you have to be ready to lose a lot of product (yields reduced by half) and the same goes for your turnover". He tells us that they always have a privileged the environmental value as well as an economic one: "when you pick only half of the product, your production cost is obviously doubled. That way your viability is at risk". He admits that profitability is necessary for keeping the business alive because it is what they live with. Hence, it is always a matter of finding a delicate balance between these elements, but interviewee J makes sure that "we are led by nature, which sometimes proves to be generous, sometimes not. Thanks to our experience, we can survive in bad years, releasing bottles kept in our inventories". He confesses that they made the choice to value the physical environment more, rather than economic profitability: "When we wake up in the morning, we are happy ... Sometimes I have personal thoughts: If it wasn't for this multi-secular tradition that I feel accountable for, I am not sure I would have been capable of doing the same choices".

Non-financial indicators (P2) are also of interest for some of our interviewees. For instance, the Italian interviewee, D, indicates that "one challenging aspect is to get insights directly from consumers". Being close to the market seems to be a key success factor for him. This regular attention to the evolution of his clients' needs enables him to adapt his wines to market trends. The Italian respondent, $\mathrm{B}$, is more concerned regarding her work staff: " . . employee turnover and satisfaction are leading measures for us". The French interviewee, E, highlights that "the key factor is the ability to sell your wine. Our wine is sold through agents in France and abroad". The French interviewee, E, seems to be focused on brand management. She goes further on this point, explaining that the most important aspect for her is to speak properly about her brand to different stakeholders. She also pays particular attention to the recruitment of her agents in France and abroad. Another French respondent, A, considers that "learning is as important, if not more, as the financial perspective". She feels very concerned with the management of her employees. That is also the case for French respondent, F, who explains how employees' well-being constitutes a real competitive advantage. His participative management style creates a positive atmosphere within the company. Spontaneously, he admits: " .. we got candidatures from people working for other wineries". The French participant, J, notes that biodiversity and ecosystem preservation are key terms and measures: "Different species of flowers are present only here, for instance. rare amphibians, mice, and snakes are everywhere in the property, but not around elsewhere. No tractors are used, only horses for laboring".

Regarding operational efficiency (P3), the French interviewee, C, feels very concerned by the efficiency of his workforce "we particularly apply the productivity ratio (worked hours/Ha)", whereas the Italian respondent, D, gives a more comprehensive answer, considering collective effort as a key factor: "We collectively make efforts to perform continuous improvements, in operational terms". The organizational choices are of importance for the French interviewee, E, who has decided to focus on her core business: 
wine production. Therefore, she explains that she "decided to outsource the low value added tasks like bottling and storage". The French participant, E, adds "... I need my staff to perform following the principle of continuous improvement". Another French respondent, G, whose "Domaine" has been managed by several generations of winemakers (five in total) has developed a good portfolio of clients, especially in Japan. Export sales represent $40 \%$ of his total turnover. In France, 100\% of his wines are sold to retailers through agents. "What is important is to ensure the reproducibility of our wines ... We need to be regular when producing stylized wines". This appears to be like a differentiation strategy. He firmly considers that it is important to produce "atypical wines". The French interviewee, $\mathrm{H}$, tells us that certifications are very helpful: "we are certified Terra Vitis, we take part of the environmental management system, coordinated by the Bordeaux Wine Council". This official reward helps them implement a better cost management system and better procedures. The French interviewee, J, deals with the wine distribution issue: "Today, 80\% of our production is sold to "négociants". In the future, we want to increase our direct sales ... Our objective is to reach $50 \%$ of our production in order to get more knowledge about our customers' needs and to better control our pricing policy".

\subsection{Resources (R)}

The question of skills and capabilities (R1) is worth analyzing because the success of a strategy lies in these two factors. Our French interviewee, A, is aware of the importance of resources, noting that "strategy will depend on what kind of resources a company has". The French respondent, E, adopts a very pragmatic approach towards the determination of commercial objectives. According to her, it is important to go step by step and to fix realistic objectives in line with affordable means: "Performance is to reach an objective with our available means ..."

Another factor that is mentioned when addressing the question of resources is land and infrastructures (R2). Italian participant, D, highlights their condition of no growth possibility within traditional appellation boundaries because they had already reached the peak. The improvement of the quality of wine involves investment in new equipment and installations. Likewise, the French participant, E, mentions that "our most recent investment was for new technical equipment ... " a similar remark was made by another French respondent, $\mathrm{A}$; "we recently invested in building renovation ... " In fact, they recently invested in new eco-friendly facilities to renew their storage warehouse.

Technology (R3) is the last factor that emerged within the resources theme. The French interviewee, E, explains how they "adopted new vine growing techniques ... " whereas the Italian interviewee, B, seems to be sensitive to the environmental impact in her investment decisions "... our new buildings will meet current standards of energy savings ... " Eventually, the French interviewee, F, refers to oenological technique " ... we also tend to master key technical aspects, like ph matching ... ". Even if the backgrounds of our interviewees are quite different (oenology, finance, etc.), all of them seem to consider technology as a determining factor to enhance the quality of wine. The French participant, G, appears to be very innovative. He was one of the first winegrower to produce red wines in Gascony; a region traditionally producing white wines. He is also very keen to invest in research and development. For instance, he invested, a few years ago, in an inerting system to maintain the quality of his wine over time. For the French respondent, J, innovation is key. Technology may help to accelerate the pace toward more sustainable practices. Incidentally, a new technology (a solar-powered robot) for weed control has been invented by a member of his family.

\subsection{Innovation (I)}

Regarding the perspectives for the future, the French interviewee, J, highlights innovation, experience-sharing, and communication. Considering new products/services (I1), our French interviewee, A, informed us that she is interested in developing "new varietal wines-shifting from traditional blended wines—and a new tasting room". This remark reflects a great sense of adaptation to new consumer needs. That position was confirmed by another French respondent, E, who noted that: "Innovation is a key word for our organization". She values spending time with retailers, from whom she 
can get important information about final consumers' tastes and needs. The French interviewee, G, has developed an in-depth strategy thinking. For instance, during the interview he put an emphasis on his range of products. The first wine (white and red) was based on tradition; the communication was focused on know-how, terroir, etc. The newest products are entry-level wines that aim to be more trendy (new colored labels). "You have to make sure we're not confusing consumers". He admits to making a consistent effort to add to the prestige of his new range of wine. "I wanted to put a smart product on the market". The manager claims himself to be an innovator. "In the wine industry, we start from scratch ... We have a lot to do". The French respondent, $\mathrm{H}$, explains to us how the markets and consumers' tastes change. "We are considered as a traditional Bordeaux, with a classic line of dry white and red wine... Our challenge is to keep our attractiveness... Our mission is to defend our family base values and traditions and, at the same time, to pass these values to younger generations of consumers and make sure they also love our wine". He goes further, explaining the need to educate the young consumers' palate and communicate with them effectively through events (tastings, after-works, etc.) because "we need constantly to find new ways to present our wine". The French interviewee, I, is eager to have differentiation. He develops this point, arguing that it is of importance to be distinctive. This Bordeaux wine estate owner works hand in hand with a young talented oenologist who thrives producing exceptional and typical wine. According to the French interviewee, I, ten to fifteen year-old wine is no more adapted to the market: "one has to innovate with new wine".

Regarding quality (I2), our French participant, E, considers that: "his wine estate is focused on quality in order to match consumers' needs". The concern for quality is shared by the Italian interviewee, D, who points out: "Because of the massive presence of global actors, the average quality is growing. We need to stay focused on quality... There won't be room for everyone". This highlights the need for differentiation factors within an extreme competitive environment. The French interviewee, I, also considers that innovation should be focused on the quality of organic wine. According to him, organic farming is more challenging than traditional wine-making but it corresponds to a strong concern to find 'life in wine'.

Dealing with sustainability (I3), the French interviewee, A, adopts a long-term vision: "I want to make sure that my sons and their kids can choose to live and work here, so I am acting for them". The Italian interviewee, B, stresses the importance of sustainability in the management of her estate: "Our global approach to sustainability is our most valuable activity, we want to preserve the environment, biological and cultural diversity, social justice, and happiness in the workplace". For illustration purposes, she explains to us that they only hire full-time workers with decent salaries. For the French respondent, C, sustainability has been at stake for a long time: "Our wine estate has been involved in sustainable practices for many years ... since the 1980s. We focus on environmental issues and measures, but also care about human aspects". Finally, the French interviewee, E, illustrates her awareness of sustainable practices through her experience in organic wine: "We are very sensitive to environmental aspects, we follow organic wine production specifications".

Owning a scientific background, the French participant, I, also has a strong belief in organic farming and in natural wine. He entered into this process more than ten years ago. At this time, "my objective was not a commercial one. My unique concern now is to protect the environment and human beings". Thus, the owner decided to eliminate any chemical products like pesticides by choosing organic farming. The wine estate was then certified by ECOCERT, which is the control and certification organization whose activities are governed by French Public Authorities and Legislation. Today, no herbicide or chemical treatments are used; only products admitted for organic certification like "Bouillie bordelaise" (Bordeaux Mixture) or sulphur crystals. Tillage is done mechanically and pruning manually. The harvests are hand-picked and, for optimum quality, a strict sorting of the grapes is put in place. It does lead to a very low yield. The French interviewee, I, confirms to us that his goal is "to find life in wine". That is the reason why he has decided to adopt an environmentally friendly organic approach. The French respondent, J, is a General Manager and sales representative. He joined the family wine estate four years ago and now manages the winery with his uncle. Since its creation, the estate has been managed 
under the principles of organic farming: "We are very attached to this place, which represents our lifestyle, we have chosen to live here, it is not only a workplace ... so, we take care of our environment, which is so fragile, we must protect it ... We want to protect this way of life, our good living". He further comments: "We never consider being organic oriented as a choice, but rather a kind of mission for us. We received this (natural) heritage from our ancestors ... We always try to preserve the environment and be knowledgeable about wildife (birds in particular)".

The French interviewee, J, feels accountable for protecting the environment: "I must act according to nature. I must respect it and put forward the work my family has always done". The Italian participant, K, also stresses his strong belief in organic principles: "we only use a little amount of sulphate, both in the fields (powders) and in the cellar (meta-bisulphate) in order to maintain hygienic standards and prevent major diseases and oxidation". He tells us that it does not constitute a real effort for him: "In our area, we have always acted that way. There is nothing new for us".

The Italian climate helped in maintaining such sustainable practices: "In these windy hills (700 meters above sea level), grapes grow naturally well, without big efforts, it is our great advantage. The presence of common grape diseases like mildew and oidium is very limited here". Actually, the wine growers in this region have always worked that way: "There is no relevant comparison with large regions where agriculture (and viticulture) is managed under industrial principles". The Italian participant, $\mathrm{K}$, notes a new trend of development in the area: "Young generations are coming back to work on the fields, this is positive ... Should they follow the example of other highly respected wine areas like Barolo (in Piedmont, Italy) or Montalcino (in Tuscany, Italy), a commercial development could emerge".

\subsection{Value creation $(V)$}

Business enterprises create and deliver value to customers. Considering brand development (V1), our French interviewee, A, views brand as a way to differentiate from competitors: "Brand development is necessary to gain competitive advantage against other winegrowers in the same area". In the wine industry, the concept of reputation has always been linked to quality. The French respondent, $C$, shares this point of view, noting that "we strive to build a positive family-owned wine business reputation". Another idea is developed by a respondent, E, about performance. According to her, a long-term vision is necessary: "A competitive company is one that lasts". From this perspective, she makes continuous efforts to maintain the brand image of her wine. The French interviewee, $G$, is a real entrepreneur who has a technical background (Engineer). From the start, this dynamic winegrower thrived, developing strong brands through communication about the history of his family and traditions. He gives us a very clear idea about the importance of a business model: "My model consists of maintaining my estate (patrimony) at a good level ... To that end, we need to build well-established brands". The French participant, $\mathrm{H}$, also insists on the importance of brand. He considers that the Internet and social media are good ways to manage them. The French respondent, I, explains to us that, where wine is renowned, it is possible to manage scarcity. The good reputation of a wine enables its sale at a reasonable price. Therefore, he comments "it seems necessary to enhance the reputation of our wine to be able to have an independent pricing policy (not to follow the average prices in a given appellation). The management of scarcity should deal with around $20 \%$ of our yearly production; the remaining $80 \%$ being intended to constitute a kind of working capital".

Financial flows (V2) are the outcome of the business model concept. In that sense, our Italian interviewee, D, notes " ... we focus on price positioning and higher margins ... that high prices are not a disadvantage in as much as you keep high quality standards over time." Beside the pricing policy, another way to enhance the cash generated by the business model is to shortcut intermediaries when selling wine. This option has been chosen by our French interviewee, A, who explains "we sell the majority of our wine directly to customers".

Knowledge sharing (V3) is also a way to enhance value. The family-owned wine estate managers' abilities can be expressed through their communication skills. Hence, the Italian interviewee, B, notes "communication - both to staff and customers - is important to us in order to raise awareness around our strategy and approach to business". At a collective level, some forms of innovation can arise 
and contribute to knowledge enhancement. The French interviewee, C, takes the example of his involvement in sustainability: "We are actively involved in our local area in the collective development of knowledge about sustainable practices and awareness around their importance". Following the same idea, the Italian interviewee, D, mentions "making an effort to share our collective experience will have a positive effect on the competitiveness of our wine". The French participant, E, stresses the importance of internal communication as a way to involve her employees. About the allocation of her working time, she acknowledges that "three quarters of my time is dedicated to the management of our employees". The French interviewee, J, points out that raising collective knowledge and awareness is a necessity. He participates in the organization of a local festival that aims to promote healthy lifestyles and organic viticulture locally and to share practices. The French interviewee, J, admits that his company faces strong competition. Moreover, his clients do not value the way he provides them organic wine. The Italian interviewee, $\mathrm{K}$, notes that knowledge sharing with other winegrowers is essential: "We have made, and we are making, a good collective work, which is the key... In ten years we progressed a lot: Every year new wineries are born; three new wineries just last year. Currently, we are 15 bottling companies; small sized companies and family based activities, of course". Moreover, he stresses the fact that "all our customers and partners celebrate our way of producing wine; that is the reason why we are currently so demanding. We cannot change this".

\section{Discussion}

This section discusses the growing attention to social and environmental issues in the wine industry and the business models of the wine companies that evolved from the interviews. So far, the empirical data has been analyzed to address the possible components of a business model. Sustainable business models help to understand how a firm creates and delivers value to its customers, which eventually yields profits [17]. The proposed business model is developed based on the main findings that emerged from the empirical study at the wine producers, supported by the previous literature.

All our interviews, conducted from 7 May 2015 to 23 June, 2017, revealed a strong concern from all the owners or general managers for sustainable practices. Sustainability appears to be a real way to understand a business model. The study explores the owners/managers' perception of the sustainability and environmental issues that are reflected in a business model in the wine industry. Most specifically, the paper identifies the four main elements, i.e., performance, resources, innovation, and value creation (PRIV) of a business model for wine companies. From our interviewees' (owners/managers) perspective, the intensity of each component and sub-themes seems to be specific to each wine estate.

The PRIV model has been evolved using four interesting components, i.e., performance $(\mathrm{P})$, resources (R), innovation (I), and value creation $(\mathrm{V})$. Interestingly, the respondents relate sustainability to the wine industry while discussing the business model. They make efforts to ensure a more sustainable future at the forefront of a business model of the wine industry.

This gives them an opportunity for the innovation of sustainable processes and products in the pursuit of better performance $(P)[26,32]$, thereby giving them a sustainable competitive advantage [33]. Firms that possess resources (R) are more likely to gain competitive advantage [34,35]. The wineries can generate a set of capabilities (R1) that facilitate innovations in product development [36]. Sustainability (I3) practice is treated as an important part of a firm's capabilities that also contributes to business performance [37-39]. Innovation (I) is a driver for value creation (V) [40]. As a result, innovation is a key element of business model design that figures out how to capture value [17].

The growing interest in environmental sustainability issues has changed the way in which a wine company operates. There are a growing number of companies that embrace sustainability and integrate it into their entire business model [9] As Giuliani [41] observes, the wine industry has undergone significant advances in production processes, involving improvements in the practices of wine grape cultivation and wine production. There is no doubt that investments in improved environmental management will increase production costs, which will lead to reduced profits [26]. Because customers welcome environmentally friendly wine and sustainability practices in wine businesses, this allows the 
wine producers to charge a higher price for their product [26,42]. a shift in producers' attitudes towards environmental responsibility by eliminating pollution waste will actually improve competitiveness in the long run [43]. Proactive environmental performance can provide the wine companies with competitive advantages via differentiation of their products. The wine produced without lasting harm increases the company's reputation as a good corporate citizen [26,39]. a consumer's trust in the winery seems to increase when wine producers adopt proactive environmental policies [26,44].

Although one of the French winery owners has mentioned winery size, which influences sustainability attitudes and practices, we have not found any clear relation between winery size and sustainable practices. Spielmann [45] examined actual firm size, which may influence management's propensity to engage in environmental sustainability practices. The author explains that larger wineries are more engaged in practicing environmental sustainability than smaller wineries. What we noticed in the field is that small wineries were also involved in sustainable practices. Small wineries that have decided to produce natural wines are aware of the risks they take. They know that it may be tricky for them to find an economic balance on a short-term basis. These winery owners usually adopt a long-term vision (today's investments may generate profits in the long-run). Moreover, these winegrowers are fully convinced that adopting sustainable practices is good for the environment (soil preservation, protecting biodiversity, etc.). They are truly driven by an environmentally friendly way of thinking. They have adopted a lifestyle in line with environment protection. In their daily activities, they are also focused on the brand image and the reputation of their wines. Their main concern is to produce high-quality wines.

The findings reported in this paper provide insights into the phenomena surrounding the business model of a wine company, showing sustainability and environmental issues to be critical to the business model. From the existing literature and the empirical work at the wine companies, there emerges an integrated account of the key components of a business model. Interviewees in the empirical study identified four integral components of a business model. One of its contributions to this literature are the components of the business model that relate sustainability to the wine industry. The results of the present study indicate the interplay between sustainability, ecological forces, and business models in wine companies.

\section{Conclusions}

There has been a steady movement in the wine industry towards environmentally sustainable wine farming, processing, and business practices $[26,46]$. This paper offers a business model conceptualization to reflect what takes place in the wine companies under investigation in terms of environmental sustainability issues in the wine industry. In essence, the paper launches new ways of thinking in a business model in the wine industry. The key global wine producers are proactive in pursuing sustainability business, maintaining the planet, and gifting the business to future human generations [26,39]. Because the wine industry is no longer a traditional industry, the paper sheds some light to better understand the business models of family owned wineries. In order to achieve this, we have conducted eleven semi-structured interviews in France and Italy involving both the wine estate owners and managers. Our qualitative approach based on the Russell, Wutich, and Ryan [31] research protocol helped us identify the four main themes, broken down into twelve sub-themes. It appears evident that major internal and external environmental forces within the wine sector are pushing organizations to review their business model. The business model redesign starts using dimensions like performance, resources, innovation, and value proposition. Our research highlights the use of sustainable practices in a business model. This study proposes a model for future applications in the winery businesses. The sustainability and environmental issues are reflected in business models in the wine industry. The findings of this study will help to understand that wine producers are very keen to be environmentally friendly wine businesses.

This study is not free from its limitations. It is based on a sample of eleven respondents who may not be representative of the broader population. Because the samples were drawn only from a few 
wine companies from two countries based in Europe (i.e., France and Italy), the results may not be comprehensive. To overcome this limitation, the study could be expanded into other economies to develop a robust framework for business models. The emphasis of this research is on the perceptions of owners and managers, which are always open to multiple interpretations. Although the research has employed a qualitative research approach, 11 wineries is not a large sample. Another opportunity would be to conduct a quantitative study in order to incorporate a larger sample of surveys and identify potential relationships between the components of a business model. a quantitative study is warranted to test the independent variables and their interrelationships with the dependent variable. Future research could investigate the mediating or moderating role of sustainability in the connection between business model elements and performance.

Author Contributions: All authors contributed equally to this manuscript. All authors have read and agreed to the published version of the manuscript.

Funding: This research received no external funding.

Acknowledgments: I would like to thank the Editor, Assistant Editor, and the three anonymous reviewers who offered extraordinarily detailed comments that pointed out many areas I had previously overlooked.

Conflicts of Interest: The authors declare no conflict of interest.

\section{References}

1. Wirtz, B.W.; Pistoia, A.; Ullrich, S.; Gottel, V. Business models: Origin, development and future research perspectives. Long Range Plan. 2016, 49, 36-54. [CrossRef]

2. Ladib, N.B.R.; Lakhal, L. Alignment between business model and business strategy and contribution to the performance: Empirical evidence from ICT Tunisian venture. J. High Technol. Manag. Res. 2015, 26, 168-176. [CrossRef]

3. Johnson, M.W.; Christensen, C.M.; Kagermann, H. Reinventing Your Business Model. Harv. Bus. Rev. 2008, 86, 51-59.

4. Chesbrough, H.; Rosenbloom, R.S. The role of the business model in capturing value from innovation: Evidence from Xerox Corporation's technology spin-off companies. Ind. Corp. Chang. 2002, 11, 529-555. [CrossRef]

5. Magretta, M. Why business models matter. Harv. Bus. Rev. 2002, 80, 86-92.

6. Casadesus-Masanell, R.; Ricart, J.E. From Strategy to Business Model and to Tactics. Long Range Plan. 2010, 43, 195-215. [CrossRef]

7. Zott, C.; Amit, R. The business model: a theoretically anchored robust construct for strategic analysis. Strateg. Organ. 2013, 11, 403-411. [CrossRef]

8. Zott, C.; Amit, R. Business model design: An activity system perspective. Long Range Plan. 2010, 43, 216-226. [CrossRef]

9. Presenza, A.; Natalicchio, A.; Petruzzelli, A.M. Editorial Business Model Innovation for Sustainability. Highlights from the Tourism and Hospitality Industry. Sustainability 2019, 11, 212.

10. Lopes, C.M.; Scavarda, A.J.; Vaccaro, G.L.R.; Pohlmann, C.R.; Korzenowski, A.L. Perspective of Business Models and Innovation for Sustainability Transition in Hospitals. Sustainability 2019, 11, 5. [CrossRef]

11. Knight, H.; Megicks, P.; Agarwal, S.; Leenders, M.A.A.M. Firm resources and the development of environmental sustainability among small and medium-sized enterprises: Evidence from the Australian wine industry. Bus. Strategy Environ. 2018, 28, 25-39. [CrossRef]

12. Christ, K.L.; Burritt, R.L. Critical environmental concerns in wine production: an integrative review. J. Clean. Prod. 2013, 53, 232-242. [CrossRef]

13. Bocken, N.M.P.; Short, S.W.; Rana, P.; Evans, S. a literature and practice review to develop sustainable business more archetypes. J. Clean. Prod. 2014, 65, 42-56. [CrossRef]

14. Ritter, T.; Letti, C. The wider implications of business-model research. Long Range Plan. 2018, 51, 1-8. [CrossRef]

15. Osterwalder, A.; Pigneur, Y. Business Model Generation: a Handbook for Visionaries, Game Changers, and Challengers; John Wiley \& Sons: Hoboken, NJ, USA, 2010. 
16. Baughman, A.; Brown, E.; Brummett, W.; Dramko, J.; Goldstein, J.; Hooper, B. California Winemaking Impact Assessment. Available online: http://www.bren.ucsb.edu/research/2000Group_Projects/Wineries/Public/ CWIAprop.pdf (accessed on 23 March 2020).

17. Teece, D.J. Business Models, Business Strategy and Innovation. Long Range Plan. 2010, 43, 172-194. [CrossRef]

18. Achtenhagen, L.; Melin, L.; Naldi, L. Dynamics of Business Models-Strategizing, Critical Capabilities and Activities for Sustained Value Creation December. Long Range Plan. 2013, 46, 427-442. [CrossRef]

19. Foss, N.J.; Saebi, T. Fifteen years of research on business model innovation: How far have we come, and where should we go? J. Manag. 2017, 43, 200-227. [CrossRef]

20. Linder, J.C.; Cantrell, S. Changing Business Models: Surveying the Landscape. Inst. Strateg. Chang. Accent. 2000, 24, 1-15.

21. Morris, M.; Schindehutte, M.; Allen, J. The entrepreneur's business model: Toward a unified perspective. J. Bus. Res. 2005, 58, 726-735. [CrossRef]

22. Belz, F.M.; Peattie, K. Sustainability Marketing; John Wiley \& Sons Ltd.: Chichester, UK, 2009.

23. Olaru, O.; Galbeaza, M.A.; Bănacu, C.S. Assessing the Sustainability of the Wine Industry in Terms of Investment. Procedia Econ. Finance 2014, 15, 552-559. [CrossRef]

24. Berns, M.; Townend, A.; Khayat, Z.; Balagopal, B.; Reeves, M.; Hopkins, M.S.; Krushwitz, N. Sustainability and competitive advantage. Sloan Manag. Rev. 2009, 51, 19-26.

25. Carrillo-Hemosilla, J.; del Rio, P.; Könnölä, T. Diversity of eco-innovations: Reflections from selected case studies. J. Clean. Prod. 2010, 18, 1073-1083. [CrossRef]

26. Gilinsky, A.; Newtona, S.K.; Vegab, R.F. Sustainability in the global wine industry: Concepts and cases. Agric. Agric. Sci. Procedia 2016, 8, 37-49. [CrossRef]

27. Forbes, S.L.; Cohen, D.A.; Cullen, R.; Wratten, S.D.; Fountain, J. Consumer attitudes regarding environmentally sustainable wine: An exploratory study of the New Zealand marketplace. J. Clean. Prod. 2009, 17, 1195-1199. [CrossRef]

28. Gemmrich, A.; Arnold, R. Sustainable winegrowing, is it sustainable or just another fad?-An international overview. Ann. Agric. Sci. 2007, 5, 87-90.

29. Tyler, B.; Lahneman, B.; Beukel, K.; Cerrato, D.; Minciullo, M.N.; Spielmann, N.; Cruz, A.D. SME Managers' Perceptions of Competitive Pressure and the Adoption of Environmental Practices in Fragmented Industries: a Multi-Country Study in the Wine Industry. Organ. Environ. 2018. [CrossRef]

30. Borsellinoa, V.; Migliorea, G.; D'Acquistoa, M.; Francoa, C.P.D.; Asciutoa, A.; Schimmentia, E. Green' Wine through a Responsible and Efficient Production: a Case Study of a Sustainable Sicilian Wine. Prod. Agric. Agric. Sci. Procedia 2016, 8, 186-192. [CrossRef]

31. Russell, B.H.; Wutich, A.; Ryan, G.W. Analyzing Qualitative Data, Systematic Approach, 2nd ed.; Sage Publication, Inc.: Thousand Oak, CA, USA, 2017.

32. York, J.G.; Venkataraman, S. The entrepreneur-environment nexus: Uncertainty, innovation, and allocation. J. Bus. Ventur. 2010, 25, 449-463. [CrossRef]

33. Porter, M.; van der Linde, C. Green and competitive: Ending the stalemate. Har. Bus. Rev. 1995, 73, $120-134$.

34. Dangelico, R.M.; Pontrandolfo, P. Being 'Green and Competitive': The Impact of Environmental Actions and Collaborations on Firm Performance. Bus. Strategy Environ. 2015, 24, 413-430. [CrossRef]

35. Runyan, R.C.; Huddleston, P.; Swinney, J.L. a resource-based view of the small firm. Qual. Mark. Res. 2007, 104, 390-402. [CrossRef]

36. Gilinsky, A. Crafting Sustainable Wine Businesses: Concepts and Cases; Palgrave Macmillan: New York, NY, USA, 2015.

37. Wernerfelt, B. a Resource-Based View of the Firm. Strat. Manag. J. 1984, 5, 171-180. [CrossRef]

38. Barney, J.B. Firm resources and sustained competitive advantage. J. Manag. 1991, 17, 99-120. [CrossRef]

39. Gilinsky, A.; Santini, C.; Lazzerretti, L.; Eyler, R. Desperately seeking serendipity: Exploring the impact of country location on innovation in the wine industry. Int. J. Wine Bus. Res. 2008, 20, 302-320. [CrossRef]

40. Nazzaro, C.; Marotta, G.; Rivetti, F. Responsible Innovation in the Wine Sector: a Distinctive Value Strategy. Agric. Agric. Sci. Procedia 2016, 8, 509-515. [CrossRef]

41. Giuliani, E. What drives innovative output in emerging clusters? Evidence from the wine industry. SPRU Electron. Work. Pap. Ser. 2008, 169, 1-39.

42. Hill, C.W.; Jones, G.R. Strategic Management: An Integrated Approach, 9th ed.; South-Western Cengage Learning: Mason, OH, USA, 2010.

43. Porter, M.E. America's green strategy. Sci. Am. 1991, 264, 168. [CrossRef] 
44. Nowak, L.I.; Washburn, J.H. Building brand equity: Consumer reactions to proactive environmental policies by the winery. I. J. Wine Mark. 2002, 14, 5-19. [CrossRef]

45. Spielmann, N. Larger and better: Examining how winery size and foreign investments interact with sustainability attitudes and practices. I. J. Wine Bus. Res. 2017, 29, 178-194. [CrossRef]

46. Steinthal, D.; Hinman, J. The Perfect Storm, Revisited. Available online: https://static1.squarespace. com/static/533dbefce4b0b65c53504cf3/t/5564ef06e4b0215a289e2db7/1432678150052/Perfect+Storm+II+-+ december2007_wbm_perfect+storm.pdf (accessed on 23 March 2020).

(C) 2020 by the authors. Licensee MDPI, Basel, Switzerland. This article is an open access article distributed under the terms and conditions of the Creative Commons Attribution (CC BY) license (http://creativecommons.org/licenses/by/4.0/). 